\title{
Review Article \\ Review on Natural Coumarin Lead Compounds for Their Pharmacological Activity
}

\author{
K. N. Venugopala, ${ }^{1}$ V. Rashmi, ${ }^{2}$ and B. Odhav ${ }^{1}$ \\ ${ }^{1}$ Department of Biotechnology and Food Technology, Durban University of Technology, Durban 4001, South Africa \\ ${ }^{2}$ Department of Public Health Medicine, University of KwaZulu-Natal, Howard College Campus, Durban 4001, South Africa
}

Correspondence should be addressed to B. Odhav; odhavb@dut.ac.za

Received 7 October 2012; Accepted 4 February 2013

Academic Editor: Paul W. Doetsch

Copyright ( $2013 \mathrm{~K}$. N. Venugopala et al. This is an open access article distributed under the Creative Commons Attribution License, which permits unrestricted use, distribution, and reproduction in any medium, provided the original work is properly cited.

Coumarin (2H-1-benzopyran-2-one) is a plant-derived natural product known for its pharmacological properties such as anti-inflammatory, anticoagulant, antibacterial, antifungal, antiviral, anticancer, antihypertensive, antitubercular, anticonvulsant, antiadipogenic, antihyperglycemic, antioxidant, and neuroprotective properties. Dietary exposure to benzopyrones is significant as these compounds are found in vegetables, fruits, seeds, nuts, coffee, tea, and wine. In view of the established low toxicity, relative cheapness, presence in the diet, and occurrence in various herbal remedies of coumarins, it appears prudent to evaluate their properties and applications further.

\section{Introduction}

Coumarins (2H-1-benzopyran-2-one) (1) consist of a large class of phenolic substances found in plants and are made of fused benzene and $\alpha$-pyrone rings [1]. More than 1300 coumarins have been identified as secondary metabolites from plants, bacteria, and fungi [2]. The prototypical compound is known as 1,2-benzopyrone or, less commonly, as $o$ hydroxycinnamic acid and lactone, and it has been well studied. Coumarins were initially found in tonka bean (Dipteryx odorata Wild) and are reported in about 150 different species distributed over nearly 30 different families, of which a few important ones are Rutaceae, Umbelliferae, Clusiaceae, Guttiferae, Caprifoliaceae, Oleaceae, Nyctaginaceae, and Apiaceae. (See Scheme 1.)

Although distributed throughout all parts of the plant, the coumarins occur at the highest levels in the fruits (Bael fruits (Aegle marmelos) [3], Tetrapleura tetraptera TAUB (Mimosaceae) [4], bilberry, and cloudberry), seeds (tonka beans) (Calophyllum cerasiferum Vesque and Calophyllum inophyllum Linn) [5] followed by the roots (Ferulago campestris) [6], leaves (Murraya paniculata) [7], Phellodendron amurense var. wilsonii [8], and latex of the tropical rainforest tree Calophyllum teysmannii var. inophylloide [9] green tea and other foods such as chicory. They are also found at high levels in some essential oils such as cassia oil [10], cinnamon bark oil [11], and lavender oil [6]. Environmental conditions and seasonal changes could influence the incidence of coumarins in varied parts of the plant. The function of coumarins is far from clear, although suggestions include plant growth regulators, bacteriostats, fungistats, and even waste products [12].

Biosynthesis of coumarin is reviewed by Bourgaud et al. [11]. There are types of coumarins found in nature due to various permutations brought about by substitutions and conjugations; however, most of the pharmacological and biochemical studies have been done on coumarin itself and on its primary metabolite, 7-hydroxycoumarin in man [13]. Some of this earlier pharmacological work on coumarin has been reviewed [14], and other more comprehensive reviews $[13,15,16]$ deal with the occurrence, chemistry, and biochemical properties of both simple and more complex natural coumarins.

\section{Classification of Coumarins}

Natural coumarins are mainly classified into six types based on the chemical structure of the compounds (Table 1). 
TABLE 1: Different coumarin types and their pharmacological properties.

\begin{tabular}{|c|c|c|c|c|}
\hline Sl no. & Type of coumarin & General chemical structure & Example with reference & $\begin{array}{l}\text { Pharmacological } \\
\text { activity }\end{array}$ \\
\hline \multirow{14}{*}{1} & \multirow{14}{*}{ Simple coumarins } & & Coumarin [17] & Anti-inflammatory \\
\hline & & & Esculetin [18] & $\begin{array}{c}\text { Anti-inflammatory } \\
\text { Anticancer } \\
\text { Antiadipogenic } \\
\text { Antioxidant } \\
\text { Neuroprotective }\end{array}$ \\
\hline & & & Ammoresinol [19] & Antibacterial \\
\hline & & & Ostruthin [19] & $\begin{array}{c}\text { Antibacterial } \\
\text { Antifungal }\end{array}$ \\
\hline & & & Osthole [20] & $\begin{array}{l}\text { Antibacterial } \\
\text { Antifungal } \\
\text { Anticancer } \\
\text { Anticonvulsant } \\
\text { Antioxidant }\end{array}$ \\
\hline & & & Novobiocin [21] & Antibacterial \\
\hline & & & Coumermycin [22] & Antibacterial \\
\hline & & & Chartreusin [23] & $\begin{array}{l}\text { Antibacterial } \\
\text { Antitumor }\end{array}$ \\
\hline & & & Fraxin [24] & $\begin{array}{l}\text { Anticancer } \\
\text { Antiadipogenic } \\
\text { Antioxidant }\end{array}$ \\
\hline & & & Umbelliferone [25] & Antitubercular \\
\hline & & & Fraxidin [26] & $\begin{array}{c}\text { Antiadipogenic } \\
\text { Antihyperglycemic }\end{array}$ \\
\hline & & & Phellodenol A [8] & Antitubercular \\
\hline & & & Esculin, fraxetin [27] & Antiadipogenic, \\
\hline & & & $\begin{array}{c}\text { Murrayatin [28] } \\
\text { Auraptene [29] }\end{array}$ & \\
\hline \multirow{5}{*}{2} & \multirow{5}{*}{ Furano coumarins } & & Imperatorin [17] & $\begin{array}{c}\text { Anti-inflammatory } \\
\text { Antibacterial } \\
\text { Antifungal } \\
\text { Antiviral } \\
\text { Anticancer } \\
\text { Anticonvulsant }\end{array}$ \\
\hline & & & Psoralen [11] & $\begin{array}{c}\text { Antifungal } \\
\text { Anti-TB }\end{array}$ \\
\hline & & & Bergapten [25] & Anti-TB \\
\hline & & & Methoxsalen [30] & $\begin{array}{l}\text { Cytochrome P450 } \\
\text { inhibitor }\end{array}$ \\
\hline & & & Marmalde, marmelosin [29] & \\
\hline 3 & $\begin{array}{l}\text { Dihydrofurano } \\
\text { coumarins }\end{array}$ & & $\begin{array}{c}\text { Anthogenol [31] } \\
\text { Felamidin [6] } \\
\text { Marmesin, rutaretin [25] }\end{array}$ & $\begin{array}{c}\text { Antibacterial } \\
\text { Antibacterial } \\
\text { Anti-TB } \\
\text { Anti-TB }\end{array}$ \\
\hline 4 & \multicolumn{4}{|c|}{ Pyrano coumarins are of two types } \\
\hline $4 a$ & Linear type & $\mathrm{H}_{3} \mathrm{C}$ & $\begin{array}{c}\text { Grandivittin [32] } \\
\text { Agasyllin [32] } \\
\text { Aegelinol benzoate [32] } \\
\text { Xanthyletin [25] }\end{array}$ & $\begin{array}{c}\text { Antibacterial } \\
\text { Antibacterial } \\
\text { Antibacterial } \\
\text { Anti-TB }\end{array}$ \\
\hline
\end{tabular}


TABle 1: Continued.

Sl no. Type of coumarin<smiles>O=c1ccc2ccccc2o1</smiles>

SCHEME 1<smiles>O=c1oc2ccccc2c(O)c1Cc1c(O)c2ccccc2oc1=O</smiles>

4

SCHEME 3<smiles>O=c1ccc2cc(O)c(O)cc2o1</smiles>

3

SCHEME 2

The physicochemical properties and therapeutic applications of natural coumarins depend upon the pattern of substitution.

\section{Coumarins and Pharmacological Activity}

3.1. Coumarins for Anti-Inflammatory Activity. Coumarin (1) exhibits anti-inflammatory property and is used in the treatment of oedema. This removes protein and oedema fluid from injured tissue by stimulating phagocytosis, enzyme production, and thus proteolysis [17]. Another compound imperatorin (2) also shows anti-inflammatory activity in lipopolysaccharide-stimulated mouse macrophage (RAW264.7) in vitro and a carrageenan-induced mouse paw

3.2. Coumarins for Anticoagulant Activity. Dicoumarol (4) was found in sweet clover [1] and exhibited anticoagulant activity [38]. (See Scheme 3.)

Coumarins are vitamin $\mathrm{K}$ antagonists that produce their anticoagulant effect by interfering with the cyclic interconversion of vitamin $\mathrm{K}$ and its 2,3 epoxide (vitamin $\mathrm{K}$ epoxide) [44]. Vitamin $\mathrm{K}$ is a cofactor for the posttranslational carboxylation of glutamate residues to $\gamma$-carboxyglutamates on the $N$-terminal regions of vitamin K-dependent proteins (Figure 1) [45-50].

These coagulation factors (factors II, VII, IX, and $\mathrm{X})$ require $\gamma$-carboxylation for their biological activity. Coumarins produce their anticoagulant effect by inhibiting 


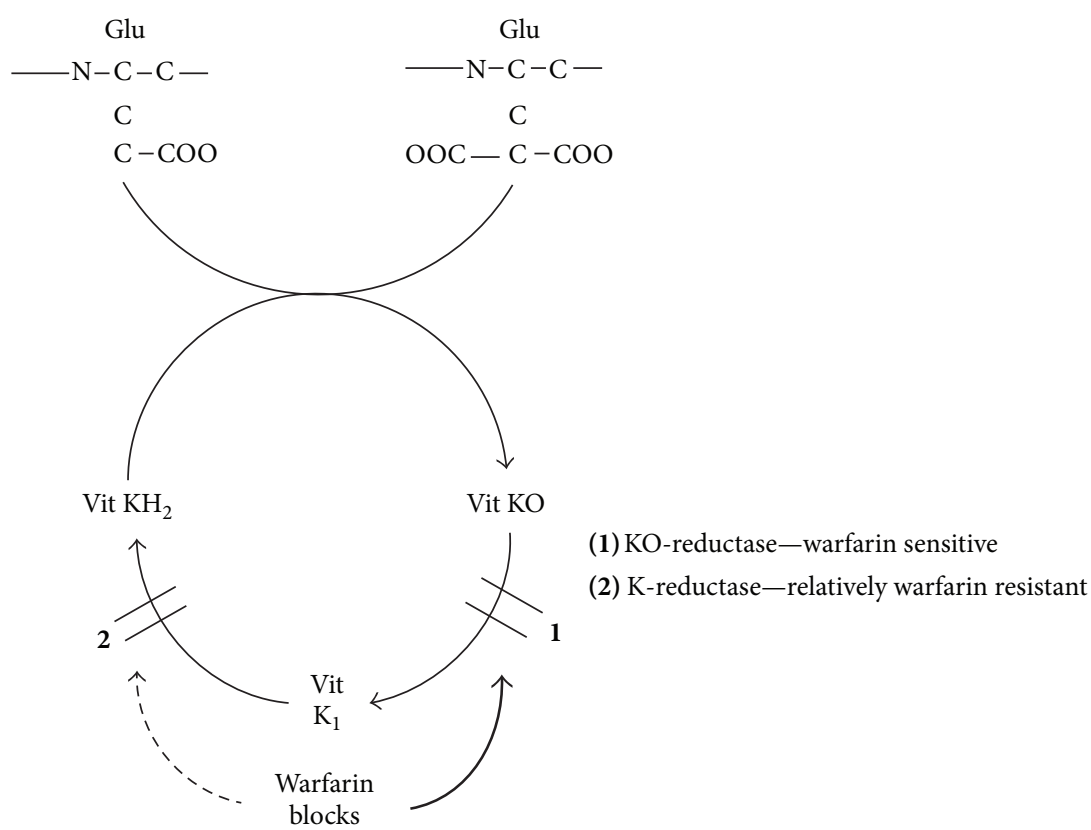

FIGURE 1: Coumarin analogue warfarin and vitamin K cycle.

vitamin $\mathrm{K}$ conversion cycle, thereby causing hepatic production of partially carboxylated and decarboxylated proteins with reduced procoagulant activity [51, 52]. In addition to their anticoagulant effect, vitamin $\mathrm{K}$ antagonists inhibit carboxylation of the regulatory anticoagulant proteins $\mathrm{C}$ and $S$ and therefore have the potential to exert a procoagulant effect. In the presence of calcium ions, carboxylation causes a conformational change in coagulation proteins [53-55] that promotes binding to cofactors on phospholipid surfaces. The carboxylation reaction requires the reduced form of vitamin $\mathrm{K}$ (vitamin $\mathrm{KH}_{2}$ ), molecular oxygen, and carbon dioxide and is linked to the oxidation of vitamin $\mathrm{KH}_{2}$ to vitamin $\mathrm{K}$ epoxide. Vitamin $\mathrm{K}$ epoxide is then recycled to vitamin $\mathrm{KH}_{2}$ through two reductase steps. The first, which is sensitive to vitamin $\mathrm{K}$ antagonist [47, 49, 50], reduces vitamin $\mathrm{K}$ epoxide to vitamin $\mathrm{K}_{1}$ (the natural food form of vitamin $K_{1}$ ), while the second, which is relatively insensitive to vitamin $K$ antagonists, reduces vitamin $K_{1}$ to vitamin $\mathrm{KH}_{2}$. Treatment with vitamin $\mathrm{K}$ antagonists leads to the depletion of vitamin $\mathrm{KH}_{2}$, thereby limiting the $\gamma$ carboxylation of vitamin $\mathrm{K}$-dependent coagulant proteins. The effect of coumarins can be counteracted by vitamin $\mathrm{K}_{1}$ (either ingested in food or administered therapeutically) because the second reductase step is relatively insensitive to vitamin $\mathrm{K}$ antagonists (Figure 1). Patients treated with a large dose of vitamin $\mathrm{K}_{1}$ can also become warfarin resistant for up to a week because vitamin $\mathrm{K}_{1}$ accumulates in the liver and is available to the coumarin-insensitive reductase.

3.3. Coumarins for Antibacterial Activity. Coumarin (1) itself has a very low antibacterial activity, but compounds having long chain hydrocarbon substitutions such as ammoresinol (5) and ostruthin (6) show activity against a wide spectrum of Gram +ve bacteria such as Bacillus megaterium, Micrococcus luteus, Micrococcus lysodeikticus, and Staphylococcus aureus [19]. Another coumarin compound anthogenol (7) from green fruits of Aegle marmelos [3] shows activity against Enterococcus. Imperatorin (2), a furanocoumarin isolated from Angelica dahurica and Angelica archangelica (Umbelliferae) [56], shows activity against Shigella dysenteriae [57]. Grandivittin (8), agasyllin (9), aegelinol benzoate (10) and osthole (11) have been isolated from the roots of Ferulago campestris (Apiaceae) [32]. Felamidin (12) was also isolated from Ferulago campestris [6]. Aegelinol and agasyllin showed significant antibacterial activity against clinically isolated Gram-positive and Gram-negative bacterial strains such as Staphylococcus aureus, Salmonella typhi, Enterobacter cloacae, and Enterobacter aerogenes. Antibacterial activity was also found against Helicobacter pylori where a dosedependent inhibition was shown between 5 and $25 \mathrm{mg} / \mathrm{mL}$. (See Scheme 4.)

Many of the natural coumarins in existence have been isolated from higher plants; some of them have been discovered in microorganisms. The important coumarin members belonging to microbial sources are novobiocin, coumermycin, and chartreusin. Novobiocin (13) was isolated as fungal metabolite from Streptomyces niveus [58] and Streptomyces spheroides and has exhibited broad spectrum antibacterial activity against Gram-positive organisms such as Corinebacterium diphtheria, Staphylococcus aureus, Streptomyces pneumoniae, and Streptomyces pyogenes and Gram-negative organisms such as Haemophillus influenzae, Neisseria meningitides, and Pasteurella [21] and has shown DNA gyrase inhibition activity [22]. Coumermycin (14), that is, structurally similar to novobiocin is nearly 50 times more potent than novobiocin, against Escherichia coli and Staphylococcus aureus, but it produces a bacteriostatic action, and the organism developed resistance gradually. Coumermycin also 
<smiles>CC(C)=CCC/C(C)=C/CC/C(C)=C/Cc1c(O)c2ccc(O)cc2oc1=O</smiles><smiles>CC(C)=CCC/C(C)=C/Cc1cc2ccc(=O)oc2cc1O</smiles><smiles>CC(C)(O)[C@H]1Oc2cc3oc(=O)ccc3cc2[C@H]1O</smiles><smiles>CC(C)=CC(=O)O[C@H]1Cc2cc3ccc(=O)oc3cc2OC1(C)C</smiles>

7<smiles>C/C=C(/C)C(=O)O[C@H]1Cc2cc3ccc(=O)oc3cc2OC1(C)C</smiles>

9<smiles>CC1(C)Oc2cc3oc(=O)ccc3cc2C[C@H]1OC(=O)c1ccccc1</smiles>

10<smiles>COc1ccc2ccc(=O)oc2c1CC=C(C)C</smiles><smiles>CC(C)(OC(=O)c1ccccc1)[C@H]1Cc2cc3ccc(=O)oc3cc2O1</smiles>

SCHEMe 4<smiles>CO[C@H]1[C@@H](OC(=O)c2ccc(C)[nH]2)[C@@H](O)[C@H](Oc2ccc3c(O)c(NC(=O)c4c[nH]c(C(=O)Nc5c(O)c6ccc(O[C@@H]7OC(C)(C)[C@@H](OC)[C@H](OC(=O)c8ccc(C)[nH]8)[C@H](O)[C@H]7OC)c(C)c6oc5=O)c4C)c(=O)oc3c2C)OC1(C)C</smiles>

14

SCHEMe 5

inhibits the supercoiling of DNA catalyzed by Escherichia coli DNA gyrase [22]. (See Scheme 5.)

Chartreusin (15) was isolated from Streptomyces chartreusis and has an uncommon structure and was predominantly active against Gram-positive bacteria [38], but due to its toxicity, the compound has not been tried for therapeutic application. (See Scheme 6.)

3.4. Coumarins for Antifungal Activity. Osthole (11) is a bioactive coumarin derivative extracted from medicinal 
<smiles>CO[C@H]1[C@@H](O)[C@@H](C)O[C@@H](O[C@H]2C(Oc3cccc4c(O)c5c(=O)oc6ccc(C)c7c(=O)oc3c4c5c67)O[C@H](C)[C@@H](O)[C@@H]2O)[C@@H]1O</smiles>

15

SCHEMe 6

plants such as Angelica pubescens [59], Cnidium monnieri [60], and Peucedanum ostruthium [61]. Osthole exhibited wide spectrum of antifungal activity against important plant pathogens such as Rhizoctonia solani, Phytophtora capsici, Botrytis cinerea, Sclerotinia sclerotiorum, and Fusarium graminearum [20]. A number of coumarins have been tested for antifungal activity, and the three most effective ones are psoralen (16) [11], imperatorin (2), and ostruthin (6). (See Scheme 7.)

3.5. Coumarins for Antiviral Activity. A large variety of natural products have been described as anti-HIV agents, and compounds having coumarin nucleus are among them. The inophyllums and calanolides represent novel HIV inhibitory coumarin derivatives. Inophyllum A (17), inophyllum B (18), inophyllum C (19), inophyllum E (20), inophyllum P (21), inophyllum G1 (22), and inophyllum G2 (23) were isolated from giant African snail, Achatina fulica. Inophyllums B and P (18 and 21) inhibited HIV reverse transcriptase (RT) with $\mathrm{IC}_{50}$ values of 38 and $130 \mathrm{nM}$, respectively, and both were active against HIV-1 in cell culture ( $\mathrm{IC}_{50}$ of 1.4 and $\left.1.6 \mu \mathrm{M}\right)$ [33]. (See Scheme 8.)

Two isomers, (+)-calanolide A (24) and (-)-calanolide B (25), have been isolated from the leaves of Calophyllum lanigerum (Clusiaceae). Calanolides A and B were completely protective against HIV-1 replication [34]. (+)-Calanolide A is a nonnucleoside RT inhibitor with potent activity against HIV-1. (-)-Calanolide B and (-)-dihydrocalanolide B (26) possess antiviral properties similar to those of $(+)$-calanolide A $[35,62]$. Both (+)-calanolide A and (+)-dihydrocalanolide A (27) are stable at neutral $\mathrm{pH}$ and currently under development for the treatment of HIV infections. However, at a $\mathrm{pH}<2.0$ for $1 \mathrm{~h}, 73 \%$ of the $(+)$-calanolide A was converted to $(+)$-calanolide B while $83 \%$ of $(+)$-dihydrocalanolide A was converted to $(+)$-dihydrocalanolide B [35, 62]. Previously inophyllum A (17) and (-)-calanolide B (25) were isolated from the oil of seeds of Calophyllum inophyllum Linn and Calophyllum cerasiferum Vesque, respectively. Both of them belong to the family Clusiaceae and are known for potent HIV-1 RT inhibitors [5]. (See Scheme 9.)
Pyranocoumarins such as pseudocordatolide C (28) and calanolide F (29) were isolated from extracts of Calophyllum lanigerum var. austrocoriaceum and Calophyllum teysmannii var. inophylloide (King) P. F. Stevens (Clusiaceae). Both the compounds exhibited anti-HIV activity [36]. Imperatorin (2) also inhibits either vesicular stomatitis virus pseudotyped or gp160-enveloped recombinant HIV-1 infection in several Tcell lines and in HeLa cells [63]. (See Scheme 10.)

3.6. Coumarins for Anticancer Activity. Imperatorin (2) exhibited anticancer effects [64]. Osthole (11) is effective in inhibiting the migration and invasion of breast cancer cells by wound healing and transwell assays. Luciferase and zymography assays revealed that osthole effectively inhibits matrix metalloproteinase-s promoter and enzyme activity, which might be one of the causes that lead to the inhibition of migration and invasion by osthole [65]. Esculetin (3) exhibited antitumor activities [66] and rescues cultured primary neurons from $N$-methyl-D-aspartate toxicity [67]. Protective effects of fraxin (30) against cytotoxicity induced by hydrogen peroxide were examined in human umbilical vein endothelial cells [24]. Most of the coumarins grandivittin (8), agasyllin (9), aegelinol benzoate (10), and osthole (11) from Ferulago campestris plant exhibited marginally cytotoxic activity against the A549 lung cancer cell line [6]. Chartreusin (15) was shown to exhibit antitumor properties against murine L1210, P388 leukemias, and B16 melanoma [23]. $3^{\prime \prime}$-Demethylchartreusin (31) is a novel antitumor antibiotic produced by Streptomyces chartreusis and it was a structural analogue of chartreusin containing the same aglycone of chartreusin, but different sugar moieties [38]. (See Scheme 11.)

Coumarin (1) which is isolated form cassia leaf oil exhibited cytotoxic activity [10].

3.7. Coumarins for Antihypertensive Activity. Dihydromammea $\mathrm{C} / \mathrm{OB}(\mathbf{3 2})$ is a new coumarin that has been isolated from the seeds of the West African tree Mammea africana Sabine (Guttiferae) [68]. The molecular structure has been 
<smiles>O=c1ccc2cc3ccoc3cc2o1</smiles>

16

SCHEMe 7<smiles>C[C@H]1[C@H](C)[C@@H](O)c2c3c(c(c4c(-c5ccccc5)cc(=O)oc24)OC(C)(C)C=C3)O[C@@H]1C</smiles>

17<smiles>C[C@H]1Oc2c3c(c4c(-c5ccccc5)cc(=O)oc4c2O1)C=CC(C)(C)O3</smiles>

21<smiles>CCCc1cc(=O)oc2c3c(c4c(c12)OC(C)(C)C=C4)O[C@H](C)[C@H](C)[C@H]3O</smiles>

24<smiles>C[C@H]1Oc2c3c(c4c(-c5ccccc5)cc(=O)oc4c2OC(C)(C)C=C3)[C@@](O)([C@@H](C)O)[C@@H]1C</smiles>

18<smiles>C[C@@H]1CC(=O)c2c(c3c(c4c(-c5ccccc5)cc(=O)oc24)OC(C)(C)C=C3)O1</smiles>

19<smiles>C[C@H]1Oc2c3c(c4c(-c5ccccc5)cc(=O)oc4c2C(=O)[C@@H]1C)OC(C)(C)[C@@H](C)O3</smiles>

20<smiles>C[C@H]1Oc2c3c(c4c(-c5ccccc5)cc(=O)oc4c2O3)[C@H]2C[C@H]1C2(C)C</smiles>

22<smiles>C[C@H]1Oc2c3c(c4oc(=O)cc(-c5ccccc5)c4c2O3)[C@H]2CC1C2(C)C</smiles>

23

SCHEMe 8<smiles>CCCc1cc(=O)oc2c3c(c4c(c12)OC(C)(C)C=C4)O[C@H](C)[C@H](C)[C@H]3O</smiles>

25<smiles>CCCc1cc(=O)oc2c3c(c4c(c12)OC(C)(C)CC4)O[C@H](C)[C@H](C)[C@H]3O</smiles>

26<smiles>CCCc1cc(=O)oc2c3c(c4c(c12)OC(C)(C)CC4)O[C@H](C)[C@H](C)[C@H]3O</smiles>

27

SCHEMe 9

elucidated by single crystal X-ray method [69]. Antihypertensive effects of the methanol and dichloromethane extracts of stem bark from Mammea africana in $\mathrm{N}^{\omega}$-nitroL-arginine methyl ester induced hypertensive male albino Wistar rats weighing 250-300 g of 12-16-week old rats have been used in the studies [70]. Dichloromethane and methanol extracts of stem bark from Mammea africana exhibited a significant antihyperglycemic activity and improved the metabolic alterations in streptozotocin-induced male albino
Wistar diabetic rats (3-month-olds, weighing 200-250 g) [71]. Vasodilatory effects of the coumarin are reported on cultured myocardial cells as well [72]. Scopoletin (33) was isolated form the fruits of Tetrapleura tetraptera TAUB (Mimosaceae) and it produces hypotension in laboratory animals in vitro and in vivo through its smooth muscle relaxant activity [4]. Visnadine (34), an active ingredient extracted from the fruit of Ammi visnaga, exhibited peripheral and coronary vasodilator activities and has been used for the treatment 
<smiles>Cc1cc(=O)oc2c3c(c4c(c12)O[C@H](C)[C@H](C)[C@H]4O)OC(C)(C)C=C3</smiles>

28<smiles>CCCc1cc(=O)oc2c3c(c4c(c12)OC(C)(C)C=C4)O[C@H](C)[C@H](C)[C@H]3C</smiles>

Scheme 10<smiles>COc1cc2ccc(=O)oc2c(OC2OC3C(O)C(O)C(O)C(O)C3(CO)O2)c1O</smiles>

30<smiles>Cc1ccc2oc(=O)c3c(O)c4cccc(OC5O[C@@H](C)[C@H](O)[C@H](O)C5OC5O[C@@H](C)[C@H](O)[C@H](O)[C@H]5O)c4c4oc(=O)c1c2c34</smiles>

31

SCHEME 11<smiles>CCCC1CC(=O)Oc2c(C(=O)C(C)CC)c(O)cc(O)c21</smiles><smiles>COc1cc2ccc(=O)oc2cc1O</smiles>

33<smiles>CC[C@H](C)C(=O)O[C@H]1[C@H](OC(C)=O)c2c(ccc3ccc(=O)oc23)OC1(C)C</smiles><smiles>CC1(C)Oc2ccc3ccc(=O)oc3c2[C@H](O)[C@@H]1O</smiles>

35

SCHEME 12

of angina pectoris [2]. Khellactone (35) was isolated from Phlojodicarpus sibiricus and it exhibited vasodilatory action [73]. (See Scheme 12.)

3.8. Coumarins for Antitubercular Activity. Umbelliferone (36) is found in many plants and obtained by the distillation of resins belonging to the natural order Umbelliferae [27]. Umbelliferone (36), phellodenol A (37), psoralen (16) and scopoletin (33), bergapten (38), (+)-(S)-marmesin (39), $(+)-(S)$-rutaretin (40), and xanthyletin (41) were isolated from the whole plants of Fatoua pilosa. The compounds scopoletin and umbelliferone are found to be active against Mycobacterium tuberculosis $\mathrm{H}_{37} \mathrm{Rv}$ with MIC values of 42 and $58.3 \mu \mathrm{g} / \mathrm{mL}$, respectively [25]. Compounds phellodenol A, (+)-(S)-marmesin and xanthyletin exhibited activity at 60 $\mu \mathrm{g} / \mathrm{mL}$ and the remaining compounds exhibited activity at more than $119 \mu \mathrm{g} / \mathrm{mL}$. Phellodenol A was also isolated from the leaves of Phellodendron amurense var. wilsonii [8]. (See Scheme 13.)

3.9. Coumarins for Anticonvulsant Activity. Imperatorin (2) showed anticonvulsant action in mice and the $\mathrm{ED}_{50}$ values ranged between 167 and $290 \mathrm{mg} / \mathrm{kg}$. Acute neurotoxic effects in the chimney test revealed that the $\mathrm{TD}_{50}$ values for imperatorin ranged between 329 and $443 \mathrm{mg} / \mathrm{kg}$ [56]. Osthole (11) exhibited anticonvulsant action in mice and the $\mathrm{ED}_{50}$ 
<smiles>O=c1ccc2ccc(O)cc2o1</smiles>

36<smiles>O=c1ccc2cc(CCO)c(O)cc2o1</smiles>

37<smiles>COc1c2ccoc2cc2oc(=O)ccc12</smiles>

38<smiles>CC(C)(O)[C@@H]1COc2cc3oc(=O)ccc3cc2C1</smiles>

39<smiles>CC(C)(O)C1Cc2cc3ccc(=O)oc3c(O)c2O1</smiles><smiles>CC1(C)C=Cc2cc3ccc(=O)oc3cc2O1</smiles>

Scheme 13<smiles>COc1cc2ccc(=O)oc2c(O)c1OC</smiles>

42<smiles>COc1cc2ccc(=O)oc2c(O)c1O</smiles>

43<smiles>O=c1ccc2cc(OC(O)OC(CO)C(O)C(O)CO)c(O)cc2o1</smiles>

44

SCHEME 14<smiles>COc1c2occc2cc2ccc(=O)oc12</smiles>

45

SCHEME 15

values ranged between 253 and $639 \mathrm{mg} / \mathrm{kg}$ and the acute neurotoxic effects with the $\mathrm{TD}_{50}$ values ranged between 531 and $648 \mathrm{mg} / \mathrm{kg}$ [74].

3.10. Coumarins for Multiple Sclerosis. Osthole (11) could be a potential therapeutic agent for the treatment of multiple sclerosis [75].

3.11. Coumarins for Antiadipogenic Activity. Fraxidin (42), [26] fraxetin (43), fraxin (30), esculetin (3), esculin (44), and scopoletin (33) have been isolated from the stem barks of Fraxinus rhynchophylla DENCE (Oleaceae). Esculetin (3) showed the most potent antiadipogenic activity against preadipocyte cell line, 3T3-L1 by in vitro assay system [27]. (See Scheme 14.)

3.12. Coumarins for Cytochrome P450 Inhibiting Activity. Methoxsalen (8-methoxypsoralen) (45) is found in the seeds of the Ammi majus (Umbelliferae) and exhibited potent mechanism-based microsomal P 450 inhibitor in vitro [76] and single-dose methoxsalen effects on human cytochrome P 4502 A6 activity [30]. (See Scheme 15.)

3.13. Coumarins for Antihyperglycemic Activity. Fraxidin (42) inhibited the formation of inducible nitric oxide synthase [77] and showed antihyperglycemic activity [78].

3.14. Coumarins for Antioxidant Activity. Fraxin (30) showed free radical scavenging effect at high concentration $(0.5 \mathrm{mM})$ and cell protective effect against $\mathrm{H}_{2} \mathrm{O}_{2}$-mediated oxidative stress [24]. Esculetin (3) exhibited antioxidant property [79]. The antioxidant activity of the coumarins grandivittin (8), agasyllin (9), aegelinol benzoate (10), and osthol (11) was evaluated by their effects on human whole blood leukocytes and on isolated polymorphonucleated chemiluminescence [32]. Fraxin (30) and esculin (44) were characterized in stems and fruits of Actinidia deliciosa (kiwifruit) and Actinidia chinensis [80]. Fraxin (30) extracted from Weigela florida var. glabra leaves (Caprifoliaceae) protects cells from oxidative stress. 
<smiles>O=c1ccc2cc3c(cc2o1)OCO3</smiles>

46

SCheme 16<smiles>CCC(C)C(=O)c1c(O)c(CC(O)C(C)(C)O)c2oc(=O)cc(-c3ccccc3)c2c1O</smiles>

47<smiles>CCC(C)C(=O)c1c2c(c3oc(=O)cc(-c4ccccc4)c3c1O)CC(O)C(C)(C)O2</smiles>

49<smiles>CCC(C)C(=O)c1c2c(c3oc(=O)cc(-c4ccccc4)c3c1O)[C@@H]1OOC(C)(C)[C@@H]1O2</smiles>

50<smiles>[R]C(=O)c1c(O)c(CC(O)C(=C)C)c2oc(=O)cc([R])c2c1O</smiles>

SCHEMe 17

3.15. Coumarins for Neuroprotective Activity. Esculetin (3) also exhibited neuroprotective effects on cerebral ischemia/reperfusion injury in a middle cerebral artery occlusion model in mice at $20 \mu \mathrm{g} / \mathrm{mL}$ and was administered intracerebroventricularly at $30 \mathrm{~min}$ before ischemia [81].

3.16. Coumarins as Phytoalexins. Phytoalexins are oxygenated coumarin derivatives and they are produced in plants in response to fungal infection, physical damage, chemical injury, or a pathogenic process. The common property of phytoallexins is to inhibit or destroy the invading agents such as bacteria, insects, and viruses. Ayapin (46) is one among them and structurally it is 6,7-methylenedioxycoumarin. Initially it was isolated from Eupatorium ayapana (Asteraceae) [4]. Later, ayapin (46) was isolated from a number of other plants such as Helianthus annuus [8], Artemisia apiacea [2], Pterocaulon virgatum [14], and Pterocaulon polystachyum [15]. (See Scheme 16.)

\section{Identification of Coumarins from Different Sources and Their Structural Elucidation}

Coumarin compounds isodispar B (47), dispardiol B, (48), mammea $\mathrm{A} / \mathrm{AB}$ cyclo $\mathrm{E}$ (49), mammea $\mathrm{A} / \mathrm{AB}$ dioxalanocyclo F (50), disparinol D (51), and disparpropylinol B (52) have been isolated from the fruits and the stem bark of Calophyllum dispar (Clusiaceae) [37, 82, 83]. (See Scheme 17.)

Seed oil [5] and essential oils such as cinnamon bark oil [11] and lavender oil from roots (Ferulago campestris) [6], contain some amount of coumarin compound (1).

The main coumarin constituents found from the leaves of Murraya paniculata are 7-methoxy-8-(3-methyl-2oxobutoxy)-2H-chromen-2-one (53) [7] and murrayatin (54). The latter was also found in the leaves of Murraya exotica [28]. (See Scheme 18.)

Prenylcoumarins (+)-fatouain A (55), (+)-fatouain A (56), (+)-fatouain C (57), (-)-fatouain D (58), (+)-fatouain E (59), and (-)-fatouain $F(60)$, along with two new bisprenylcoumarins, (+)-fatouain $\mathrm{G}(\mathbf{5 8})$, and (+)-fatouain $\mathrm{H}$ (59), have been isolated from the whole plants of Fatoua pilosa [84]. (See Scheme 19.)

Marmin (63) is isolated from the bark. Imperatorin (2) and aurapten (64) are isolated from the fruit of Aegle marmelos (linn) Correa commonly known as Bael (or Bel) belonging to the family Rutaceae [29]. (See Scheme 20.)

\section{Analysis of Coumarins by Different Methods}

Various methods for the isolation and analysis of coumarins are chromatography (paper chromatography, thin layer chromatography, gas chromatography, and high-performance 
<smiles>COc1ccc2ccc(=O)oc2c1OCC(=O)C(C)C</smiles><smiles>COc1ccc2ccc(=O)oc2c1C[C@H](OC(=O)CC(C)C)C(C)(C)O</smiles>

SCHEMe 18<smiles>C/C=C\[C@H](O)[C@H](O)c1cc2ccc(=O)oc2c(OC)c1OC</smiles><smiles>C/C=C\[C@H](O)[C@H](O)c1cc2ccc(=O)oc2c(OC)c1OC</smiles><smiles>C/C=C\[C@H](O)[C@H](O)c1cc2ccc(=O)oc2c(O)c1OC</smiles><smiles>C/C=C\[C@H](O)[C@H](O)c1cc2ccc(=O)oc2c(O)c1OC</smiles><smiles>C/C=C\[C@H](O)[C@H](OC)c1cc2ccc(=O)oc2c(O)c1OC</smiles><smiles>C/C=C\[C@H](O)[C@H](OC)c1cc2ccc(=O)oc2c(O)c1OC</smiles><smiles>C=C(C)[C@H](O)[C@@H](O)c1cc2ccc(=O)oc2c(Oc2c(O)c(CC=C(C)C)cc3ccc(=O)oc23)c1OC</smiles><smiles>C=C(C)[C@H](O)[C@H](Oc1c2c(cc3ccc(=O)oc13)C=CC(C)(C)O2)c1cc2ccc(=O)oc2c(O)c1O</smiles>

SCHEME 19<smiles>C/C(=C\COc1ccc2ccc(=O)oc2c1)CC[C@@H](O)C(C)(C)O</smiles><smiles>C/C(O)=C/CC/C(C)=C/COc1ccc2ccc(=O)oc2c1</smiles>

SCHEME 20

liquid chromatography), titrimetric and spectrophotometric (colorimetric and polarographic) methods. Methods for the analysis of coumarin derivatives stipulated by official pharmacopoeias (US Pharmacopoeia (23rd Edition), European
Pharmacopoeia (3rd Edition, Suppl. 2001), and British Pharmacopoeia (16th Edition, 1998) and methods for coumarin determination in yellow sweet clover have been reviewed [85]. 


\section{Conclusion}

This paper covers natural coumarin lead compounds and their broad pharmacological properties and their methods of identification according to their official pharmacopoeias. Natural coumarins are of great interest due to their widespread pharmacological properties, and this attracts many medicinal chemists for further backbone derivatization and screening them as several novel therapeutic agents.

\section{Acknowledgments}

The authors thank Durban University of Technology for facilities and K. N. Venugopala is grateful to NRF, South Africa, for DST/NRF Innovation Postdoctoral Fellowship.

\section{References}

[1] Y. Aoyama, T. Katayama, M. Yamamoto, H. Tanaka, and K. Kon, "A new antitumor antibiotic product, demethylchartreusin. Isolation and biological activities," The Journal of Antibiotics, vol. 45, no. 6, pp. 875-878, 1992.

[2] M. Iranshahi, M. Askari, A. Sahebkar, and D. HadjipavlouLitina, "Evaluation of antioxidant, anti-inflammatory and lipoxygenase inhibitory activities of the prenylated coumarin umbelliprenin," DARU, vol. 17, no. 2, pp. 99-103, 2009.

[3] W. C. Evans, Trease and Evans Pharmacognosy, Elsevier Ltd., 16th edition, 2009.

[4] J. A. Mead, J. N. Smith, and R. T. Williams, "Studies in detoxication. 72. The metabolism of coumarin and of o-coumaric acid," The Biochemical Journal, vol. 68, no. 1, pp. 67-74, 1958.

[5] C. Spino, M. Dodier, and S. Sotheeswaran, "Anti-HIV coumarins from calophyllum seed oil," Bioorganic and Medicinal Chemistry Letters, vol. 8, no. 24, pp. 3475-3478, 1998.

[6] S. Rosselli, A. M. Maggio, N. Faraone et al., "The cytotoxic properties of natural coumarins isolated from roots of Ferulago campestris (Apiaceae) and of synthetic ester derivatives of aegelinol," Natural Product Communications, vol. 4, no. 12, pp. 1701-1706, 2009.

[7] Atta-ur-Rahman, M. Shabbir, S. Ziauddin Sultani, A. Jabbar, and M. I. Choudhary, "Cinnamates and coumarins from the leaves of Murraya paniculata," Phytochemistry, vol. 44, no. 4, pp. 683-685, 1997.

[8] A. J. Cohen, "Critical review of the toxicology of coumarin with special reference to interspecies differences in metabolism and hepatotoxic response and their significance to man," Food and Cosmetics Toxicology, vol. 17, no. 3, pp. 277-289, 1979.

[9] R. W. Fuller, H. R. Bokesch, K. R. Gustafson et al., "HIVInhibitory coumarins from latex of the tropical rainforest tree Calophyllum teysmannii var. inophylloide," Bioorganic and Medicinal Chemistry Letters, vol. 4, no. 16, pp. 1961-1964, 1994.

[10] J. Choi, K. T. Lee, H. Ka, W. T. Jung, H. J. Jung, and H. J. Park, "Constituents of the essential oil of the Cinnamomum cassia stem bark and the biological properties," Archives of Pharmacal Research, vol. 24, no. 5, pp. 418-423, 2001.

[11] F. Bourgaud, A. Hehn, R. Larbat et al., "Biosynthesis of coumarins in plants: a major pathway still to be unravelled for cytochrome P450 enzymes," Phytochemistry Reviews, vol. 5, no. 2-3, pp. 293-308, 2006.
[12] D. Bogdal, "Coumarins: fast synthesis by Knoevenagel condensation under microwave irradiation," Journal of Chemical Research, Synopses, no. 8, pp. 468-469, 1998.

[13] B. G. Lake, "Coumarin metabolism, toxicity and carcinogenicity: relevance for human risk assessment," Food and Chemical Toxicology, vol. 37, no. 4, pp. 423-453, 1999.

[14] D. Egan, R. O’Kennedy, E. Moran, D. Cox, E. Prosser, and R. D. Thornes, "The pharmacology, metabolism, analysis, and applications of coumarin and coumarin-related compounds," Drug Metabolism Reviews, vol. 22, no. 5, pp. 503-529, 1990.

[15] M. E. Marshall, J. L. Mohler, K. Edmonds et al., "An updated review of the clinical development of coumarin (1,2-benzopyrone) and 7-hydroxycoumarin," Journal of Cancer Research and Clinical Oncology, vol. 120, supplement, pp. S39S42, 1994.

[16] R. D. H. Murray, "Naturally occuring plant coumarins," in Progress in the Chemistry of Organic Natural Products, pp. 2-105, Springer, New York, NY, USA, 1997.

[17] N. B. Piller, "A comparison of the effectiveness of some anti inflammatory drugs on thermal oedema," British Journal of Experimental Pathology, vol. 56, no. 6, pp. 554-560, 1975.

[18] A. Witaicenis, L. N. Seito, and L. C. Di Stasi, "Intestinal antiinflammatory activity of esculetin and 4-methylesculetin in the trinitrobenzenesulphonic acid model of rat colitis," ChemicoBiological Interactions, vol. 186, no. 2, pp. 211-218, 2010.

[19] K. Hodák, V. Jakesová, and V. Dadák, "On the antibiotic effects of natural coumarins. VI. The relation of structure to the antibacterial effects of some natural coumarins and the neutralization of such effects," Cesko-Slovenska Farmacie, vol. 16, no. 2, pp. 86-91, 1967.

[20] C. M. Wang, W. Zhou, C. X. Li, H. Chen, Z. Q. Shi, and Y. J. Fan, "Efficacy of osthol, a potent coumarin compound, in controlling powdery mildew caused by Sphaerotheca fuliginea," Journal of Asian Natural Products Research, vol. 11, no. 9, pp. 783-791, 2009.

[21] E. B. Chain, "Chemistry and biochemistry of antibiotics," Annual Review of Biochemistry, vol. 27, no. 3, pp. 167-222, 1958.

[22] M. Gellert, M. H. O'Dea, T. Itoh, and J. I. Tomizawa, "Novobiocin and coumermycin inhibit DNA supercoiling catalyzed by DNA gyrase," Proceedings of the National Academy of Sciences of the United States of America, vol. 73, no. 12, pp. 4474-4478, 1976.

[23] J. Portugal, "Chartreusin, elsamicin A and related anti-cancer antibiotics," Current Medicinal Chemistry. Anti-Cancer Agents, vol. 3, no. 6, pp. 411-420, 2003.

[24] W. K. Whang, H. S. Park, I. Ham et al., "Natural compounds, fraxin and chemicals structurally related to fraxin protect cells from oxidative stress," Experimental and Molecular Medicine, vol. 37, no. 5, pp. 436-446, 2005.

[25] C. C. Chiang, M. J. Cheng, C. F. Peng, H. Y. Huang, and I. S. Chen, "A novel dimeric coumarin analog and antimycobacterial constituents from Fatoua pilosa," Chemistry and Biodiversity, vol. 7, no. 7, pp. 1728-1736, 2010.

[26] M. I. Yusupov and G. P. Sidyakin, "Fraxidin and isofraxidin from Artemisia scotina," Chemistry of Natural Compounds, vol. 11, no. 1, p. 94, 1975.

[27] E. Shin, K. M. Choi, H. S. Yoo, C. K. Lee, B. Y. Hwang, and M. K. Lee, "Inhibitory effects of coumarins from the stem barks of Fraxinus rhynchophylla on adipocyte differentiation in 3T3-L1 cells," Biological and Pharmaceutical Bulletin, vol. 33, no. 9, pp. 1610-1614, 2010.

[28] B. R. Barik, A. K. Dey, and A. Chatterjee, "Murrayatin, a coumarin from Murraya exotica," Phytochemistry, vol. 22, no. 10, pp. 2273-2275, 1983. 
[29] S. Farooq, 555 Medicinal Plants. Field and Laboratory Manual, International Book Distributors, Dehradun, India, 2005.

[30] E. D. Kharasch, D. C. Hankins, and J. K. Taraday, "Single-dose methoxsalen effects on human cytochrome P-450 2A6 activity," Drug Metabolism and Disposition, vol. 28, no. 1, pp. 28-33, 2000.

[31] S. Chakthong, P. Weaaryee, P. Puangphet et al., "Alkaloid and coumarins from the green fruits of Aegle marmelos," Phytochemistry, vol. 75, pp. 108-113, 2012.

[32] A. Basile, S. Sorbo, V. Spadaro et al., "Antimicrobial and antioxidant activities of coumarins from the roots of Ferulago campestris (apiaceae)," Molecules, vol. 14, no. 3, pp. 939-952, 2009.

[33] A. D. Patil, A. J. Freyer, D. S. Eggleston et al., "The inophyllums, novel inhibitors of HIV-1 reverse transcriptase isolated from the Malaysian tree, Calophyllum inophyllum Linn," Journal of Medicinal Chemistry, vol. 36, no. 26, pp. 4131-4138, 1993.

[34] Y. Kashman, K. R. Gustafson, R. W. Fuller et al., "The calanolides, a novel HIV-inhibitory class of coumarin derivatives from the tropical rainforest tree, Calophyllum lanigerum," Journal of Medicinal Chemistry, vol. 35, no. 15, pp. 2735-2743, 1992.

[35] R. A. Newman, W. Chen, and T. L. Madden, "Pharmaceutical properties of related calanolide compounds with activity against human immunodeficiency virus," Journal of Pharmaceutical Sciences, vol. 87, no. 9, pp. 1077-1080, 1998.

[36] T. C. McKee, R. W. Fuller, C. D. Covington et al., "New pyranocoumarins isolated from Calophyllum lanigerum and Calophyllum teysmannii," Journal of Natural Products, vol. 59, no. 8, pp. 754-758, 1996.

[37] L. Crombie, D. E. Games, and A. McCormick, "Isolation and structure of mammea $\mathrm{A} / \mathrm{BA}, \mathrm{A} / \mathrm{AB}$ and $\mathrm{A} / \mathrm{BB}$ : a group of 4-arylcoumarin extractives of Mammea americana L," Tetrahedron Letters, vol. 7, no. 2, pp. 145-149, 1966.

[38] S. K. Poole and C. F. Poole, "Thin-layer chromatographic method for the determination of the principal polar aromatic flavour compounds of the cinnamons of commerce," The Analyst, vol. 119, no. 1, pp. 113-120, 1994.

[39] G. J. Huang, J. S. Deng, J. C. Liao et al., "Inducible nitric oxide synthase and cyclooxygenase-2 participate in antiinflammatory activity of imperatorin from Glehnia littoralis," Journal of Agricultural and Food Chemistry, vol. 60, no. 7, pp. 1673-1681, 2012.

[40] A. Nadkarni, Nadkarni's Indian Materia Medica, vol. 1, Popular Prakashan Pvt. Ltd., Bombay, India, 1976.

[41] W. S. Chang, Y. H. Chang, F. J. Lu, and H. C. Chiang, "Inhibitory effects of phenolics on xanthine oxidase," Anticancer Research, vol. 14, no. 2A, pp. 501-506, 1994.

[42] O. S. Kwon, J. S. Choi, M. N. Islam et al., "Inhibition of 5lipoxygenase and skin inflammation by the aerial parts of Artemisia capillaris and its constituents," Archives of Pharmacal Research, vol. 34, no. 9, pp. 1561-1569, 2011.

[43] K. C. Fylaktakidou, D. J. Hadjipavlou-Litina, K. E. Litinas, and D. N. Nicolaides, "Natural and synthetic coumarin derivatives with anti-inflammatory/antioxidant activities," Current Pharmaceutical Design, vol. 10, no. 30, pp. 3813-3833, 2004.

[44] J. Hirsh, J. E. Dalen, D. R. Anderson et al., "Oral anticoagulants: mechanism of action, clinical effectiveness, and optimal therapeutic range," Chest, vol. 119, no. 1, supplement, pp. 8S-21S, 2001.

[45] G. L. Nelsestuen, T. H. Zytkovicz, and J. B. Howard, "The mode of action of vitamin K. Identification of $\gamma$ carboxyglutamic acid as a component of prothrombin," The Journal of Biological Chemistry, vol. 249, no. 19, pp. 6347-6350, 1974.
[46] J. Stenflo, P. Fernlund, W. Egan, and P. Roepstorff, "Vitamin $\mathrm{K}$ dependent modifications of glutamic acid residues in prothrombin," Proceedings of the National Academy of Sciences of the United States of America, vol. 71, no. 7, pp. 2730-2733, 1974.

[47] D. S. Whitlon, J. A. Sadowski, and J. W. Suttie, "Mechanism of coumarin action: significance of vitamin $\mathrm{K}$ epoxide reductase inhibition," Biochemistry, vol. 17, no. 8, pp. 1371-1377, 1978.

[48] L. S. Trivedi, M. Rhee, J. H. Galivan, and M. J. Fasco, "Normal and warfarin-resistant rat hepatocyte metabolism of vitamin $\mathrm{K}$ 2,3-epoxide: evidence for multiple pathways of hydroxyvitamin K formation," Archives of Biochemistry and Biophysics, vol. 264, no. 1, pp. 67-73, 1988.

[49] M. J. Fasco, E. F. Hildebrandt, and J. W. Suttie, "Evidence that warfarin anticoagulant action involves two distinct reductase activities," The Journal of Biological Chemistry, vol. 257, no. 19, pp. 11210-11212, 1982.

[50] I. A. Choonara, R. G. Malia, B. P. Haynes et al., "The relationship between inhibition of vitamin K1 2,3-epoxide reductase and reduction of clotting factor activity with warfarin," British Journal of Clinical Pharmacology, vol. 25, no. 1, pp. 1-7, 1988.

[51] P. A. Friedman, R. D. Rosenberg, P. V. Hauschka, and A. FitzJames, "A spectrum of partially carboxylated prothrombins in the plasmas of coumarin-treated patients," Biochimica et Biophysica Acta, vol. 494, no. 1, pp. 271-276, 1977.

[52] O. P. Malhotra, M. E. Nesheim, and K. G. Mann, "The kinetics of activation of normal and $\gamma$-carboxyglutamic acid-deficient prothrombins," The Journal of Biological Chemistry, vol. 260, no. 1, pp. 279-287, 1985.

[53] G. L. Nelsestuen, "Role of $\gamma$ carboxyglutamic acid. An unusual protein transition required for the calcium dependent binding of prothrombin to phospholipid," The Journal of Biological Chemistry, vol. 251, no. 18, pp. 5648-5656, 1976.

[54] F. G. Prendergast and K. G. Mann, "Differentiation of metal ion induced transitions of prothrombin fragment 1," The Journal of Biological Chemistry, vol. 252, no. 3, pp. 840-850, 1977.

[55] M. Borowski, B. C. Furie, S. Bauminger, and B. Furie, "Prothrombin requires two sequential metal-dependent conformational transitions to bind phospholipid. Conformation-specific antibodies directed against the phospholipid-binding site on prothrombin," The Journal of Biological Chemistry, vol. 261, no. 32, pp. 14969-14975, 1986.

[56] N. I. Baek, E. M. Ahn, H. Y. Kim, and Y. D. Park, "Furanocoumarins from the root of Angelica dahurica," Archives of Pharmacal Research, vol. 23, no. 5, pp. 467-470, 2000.

[57] S. B. Raja, M. R. Murali, K. Roopa et al., "Imperatorin a furocoumarin inhibits periplasmic $\mathrm{Cu}-\mathrm{Zn}$ SOD of Shigella dysenteriae their by modulates its resistance towards phagocytosis during host pathogen interaction," Biomedicine \& Pharmacotherapy, vol. 65, no. 8, pp. 560-568, 2011.

[58] S. Hestrin, D. S. Feingold, and G. Avigad, "Synthesis of sucrose and other $\beta$-D-fructofuranosyl aldosides by levansucrase," Journal of the American Chemical Society, vol. 77, no. 24, p. 6710, 1955.

[59] C. M. Teng, C. H. Lin, F. N. Ko, T. S. Wu, and T. F. Huang, "The relaxant action of osthole isolated from Angelica pubescens in guinea-pig trachea," Naunyn-Schmiedeberg's Archives of Pharmacology, vol. 349, no. 2, pp. 202-208, 1994.

[60] S. Y. Chou, C. S. Hsu, K. T. Wang, M. C. Wang, and C. C. Wang, "Antitumor effects of osthol from Cnidium monnieri: an in vitro and in vivo study," Phytotherapy Research, vol. 21, no. 3, pp. 226230, 2007. 
[61] W. Cisowski, U. Sawicka, M. Mardarowicz, M. Asztemborska, and M. Luczkiewicz, "Essential oil from herb and rhizome of Peucedanum ostruthium (L. Koch.) ex DC," Zeitschrift für Naturforschung C, vol. 56, no. 11-12, pp. 930-932, 2001.

[62] G. H. Stout and K. L. Stevens, "The structure of costatolide," Journal of Organic Chemistry, vol. 29, no. 12, pp. 3604-3609, 1964.

[63] R. Sancho, N. Márquez, M. Gómez-Gonzalo et al., "Imperatorin inhibits HIV-1 replication through an Sp1-dependent pathway," The Journal of Biological Chemistry, vol. 279, no. 36, pp. 3734937359, 2004.

[64] K. W. Luo, J. G. Sun, J. Y. Chan et al., "Anticancer effects of imperatorin isolated from Angelica dahurica: induction of apoptosis in HepG2 cells through both death-receptor and mitochondria-mediated pathways," Chemotherapy, vol. 57, no. 6, pp. 449-459, 2011.

[65] D. Yang, T. Gu, T. Wang, Q. Tang, and C. Ma, "Effects of osthole on migration and invasion in breast cancer cells," Bioscience, Biotechnology and Biochemistry, vol. 74, no. 7, pp. 1430-1434, 2010.

[66] E. S. Yun, S. S. Park, H. C. Shin et al., "p38 MAPK activation is required for esculetin-induced inhibition of vascular smooth muscle cells proliferation," Toxicology in Vitro, vol. 25, no. 7, pp. 1335-1342, 2011.

[67] C. R. Lee, E. J. Shin, H. C. Kim et al., "Esculetin inhibits Nmethyl-D-aspartate neurotoxicity via glutathione preservation in primary cortical cultures," Laboratory Animal Research, vol. 27, no. 3, pp. 259-263, 2011.

[68] E. G. Crichton and P. G. Waterman, "Dihydromammea C/OB: a new coumarin from the seed of Mammea africana," Phytochemistry, vol. 17, no. 10, pp. 1783-1786, 1978.

[69] C. H. Schwalbe and P. G. Waterman, "Structure of 5, 7dihydroxy-8-(2-methylbutyryl)-4-n-pentyl-3, 4-dihydrocoumarin (dihydromammea C/OB), $\mathrm{C}_{19} \mathrm{H}_{26} \mathrm{O}_{5}$, Acta Crystallographica Section C, vol. 39, no. 4, pp. 499-502, 1983.

[70] P. E. Nguelefack-Mbuyo, T. B. Nguelefack, A. B. Dongmo et al., "Anti-hypertensive effects of the methanol/methylene chloride stem bark extract of Mammea africana in 1-NAME-induced hypertensive rats," Journal of Ethnopharmacology, vol. 117, no. 3, pp. 446-450, 2008.

[71] M. C. Tchamadeu, P. D. D. Dzeufiet, C. C. K. Nouga et al., "Hypoglycaemic effects of Mammea africana (Guttiferae) in diabetic rats," Journal of Ethnopharmacology, vol. 127, no. 2, pp. 368-372, 2010.

[72] T. Namba, O. Morita, S. L. Huang, K. Goshima, M. Hattori, and N. Kakiuchi, "Studies on cardio-active crude drugs; I. Effect of coumarins on cultured myocardial cells," Planta Medica, vol. 54, no. 4, pp. 277-282, 1988.

[73] D. Gantimur, A. I. Syrchina, and A. A. Semenov, "Khellactone derivatives from Phlojodicarpus sibiricus," Chemistry of Natural Compounds, vol. 22, no. 1, pp. 103-104, 1986.

[74] J. J. Luszczki, E. Wojda, M. Andres-Mach et al., "Anticonvulsant and acute neurotoxic effects of imperatorin, osthole and valproate in the maximal electroshock seizure and chimney tests in mice: a comparative study," Epilepsy Research, vol. 85, no. 2-3, pp. 293-299, 2009.

[75] X. Chen, R. Pi, Y. Zou et al., "Attenuation of experimental autoimmune encephalomyelitis in C57 BL/6 mice by osthole, a natural coumarin," European Journal of Pharmacology, vol. 629, no. 1-3, pp. 40-46, 2010.

[76] M. Tinel, J. Belghiti, V. Descatoire et al., "Inactivation of human liver cytochrome P-450 by the drug methoxsalen and other psoralen derivatives," Biochemical Pharmacology, vol. 36, no. 6, pp. 951-955, 1987.

[77] N. Y. Kim, H. O. Pae, Y. S. Ko et al., "In vitro inducible nitric oxide synthesis inhibitory active constituents from Fraxinus rhynchophylla," Planta Medica, vol. 65, no. 7, pp. 656-658, 1999.

[78] D. M. Fort, K. Rao, S. D. Jolad, J. Luo, T. J. Carlson, and S. R. King, "Antihyperglycemic activity of Teramnus labialis (Fabaceae)," Phytomedicine, vol. 6, no. 6, pp. 465-467, 2000.

[79] S. H. Kim, K. A. Kang, R. Zhang et al., "Protective effect of esculetin against oxidative stress-induced cell damage via scavenging reactive oxygen species," Acta Pharmacologica Sinica, vol. 29, no. 11, pp. 1319-1326, 2008.

[80] A. M. Hirsch, A. Longeon, and M. Guyot, "Fraxin and esculin: two coumarins specific to Actinidia chinensis and A. deliciosa (kiwifruit)," Biochemical Systematics and Ecology, vol. 30, no. 1, pp. 55-60, 2002.

[81] C. Wang, A. Pei, J. Chen et al., "A natural coumarin derivative esculetin offers neuroprotection on cerebral ischemia/reperfusion injury in mice," Journal of Neurochemistry, vol. 121, no. 6, pp. 1007-1013, 2012.

[82] D. Guilet, D. Séraphin, D. Rondeau, P. Richomme, and J. Bruneton, "Cytotoxic coumarins from Calophyllum dispar," Phytochemistry, vol. 58, no. 4, pp. 571-575, 2001.

[83] L. Crombie, D. E. Games, N. J. Haskins, and G. F. Reed, "Extractives of Mammea americana L-part III: Identification of new coumarin relatives of mammea $\mathrm{B} / \mathrm{BA}, \mathrm{B} / \mathrm{BB}$, and $\mathrm{B} / \mathrm{BC}$ having 5,6-annulation and higher oxidation levels," Journal of the Chemical Society, Perkin Transactions 1, vol. 1972, pp. 22412248, 1972.

[84] C. C. Chiang, M. J. Cheng, H. Y. Huang, H. S. Chang, C. J. Wang, and I. S. Chen, "Prenyl coumarins from Fatoua pilosa," Journal of Natural Products, vol. 73, no. 10, pp. 1718-1722, 2010.

[85] A. V. Lozhkin and E. I. Sakanyan, "Natural coumarins: methods of isolation and analysis," Pharmaceutical Chemistry Journal, vol. 40, no. 6, pp. 337-346, 2006. 

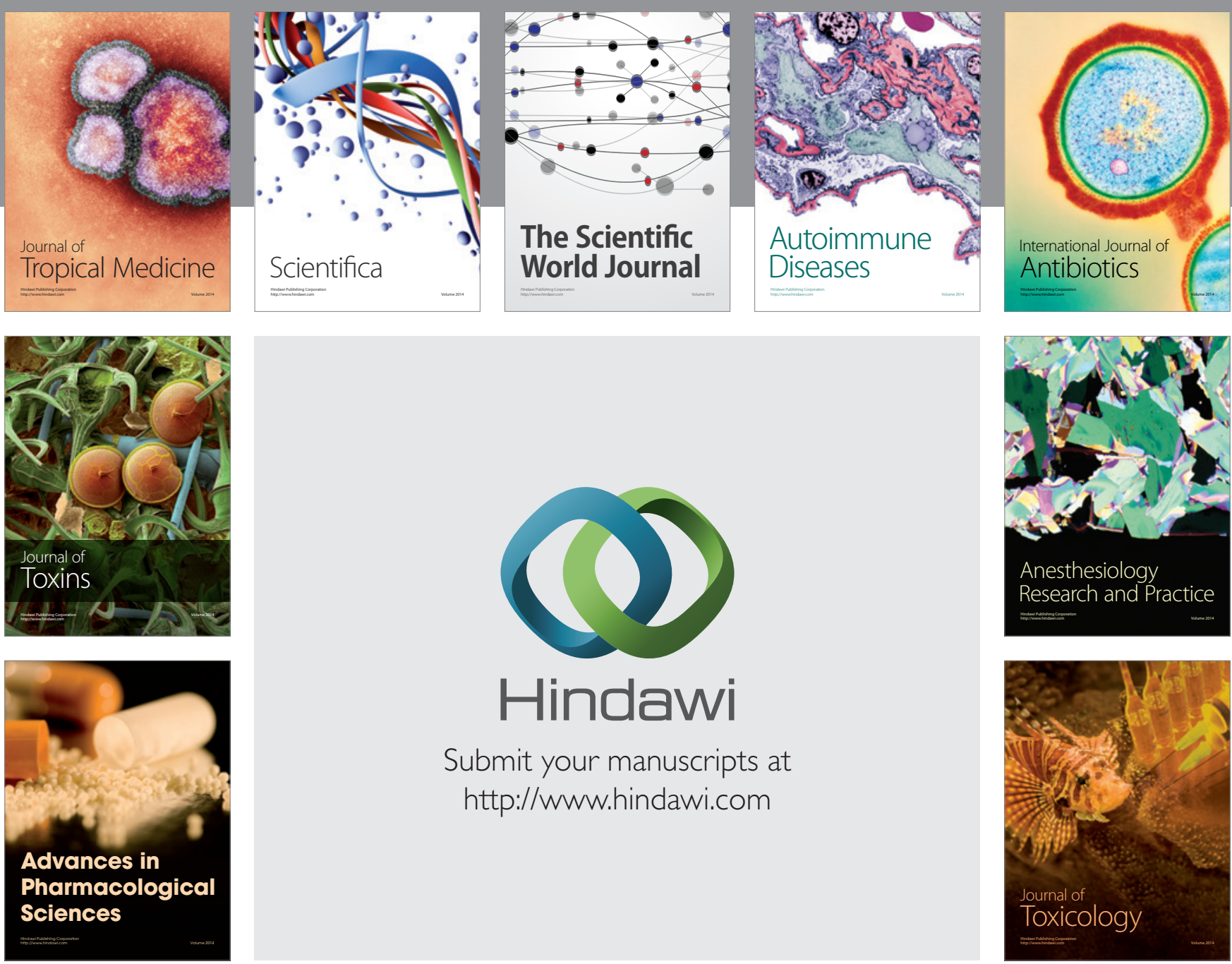

\section{Hindawi}

Submit your manuscripts at

http://www.hindawi.com
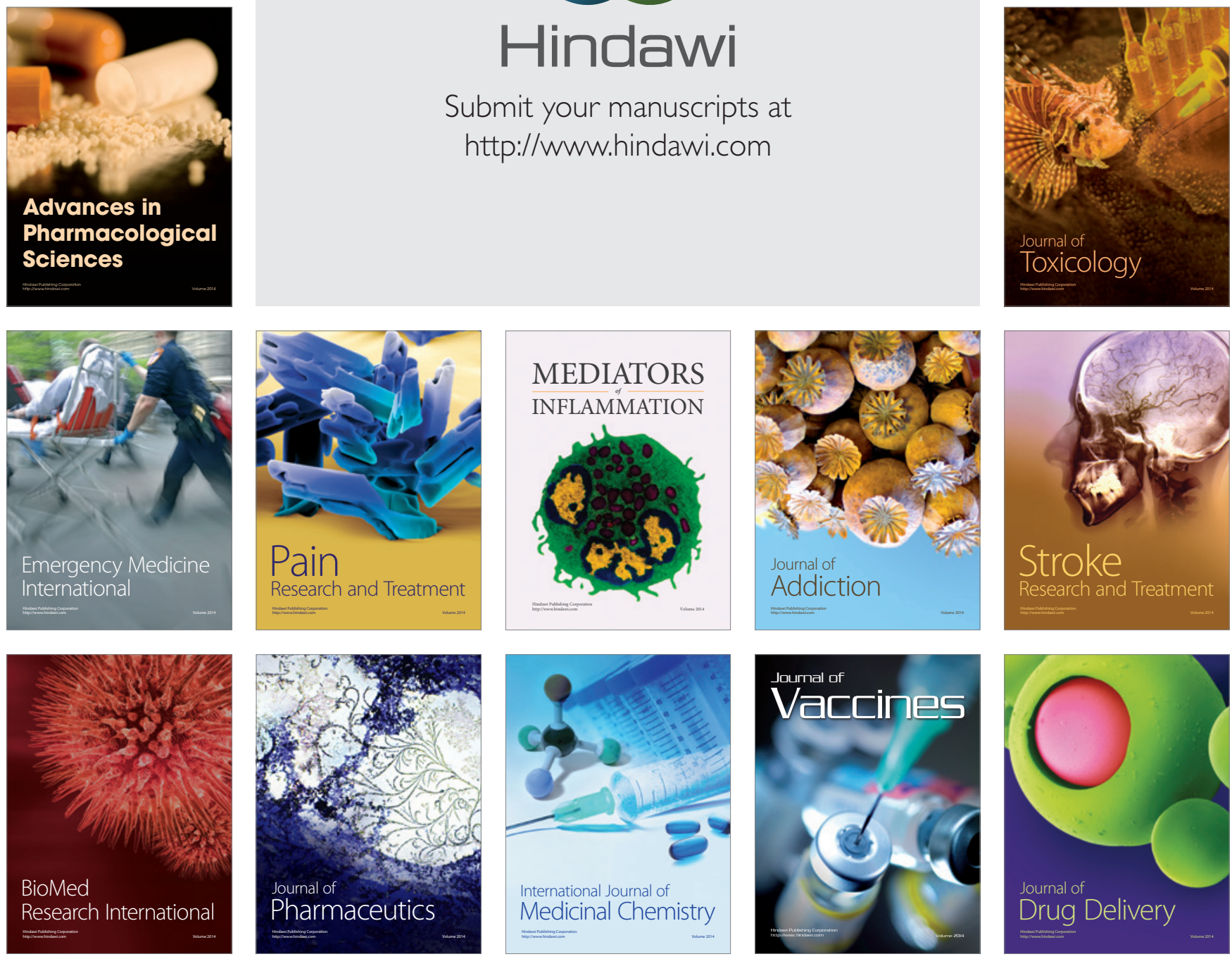